\title{
Mathematical models for irrigation and nutrient management practices to improve nitrate pollution control
}

\author{
A. M. Marinov \& T. Petrovici \\ Department of Hydraulics, Hydraulic Machinery and Environmental \\ Engineering, Faculty of Power Engineering, \\ University Politehnica of Bucharest, Romania
}

\begin{abstract}
Soil and groundwater pollution with nitrates is a major environmental concern in Romania as well as in all countries with intensive and irrigated agriculture. Methods of fertilizer application, timing, relation of nitrogen to other nutrients, cropping systems and water management influence nitrates leaching. The best solution to avoid groundwater pollution is to limit nitrogen fertilizer application to the amount likely to be used by crop, but an accurate nitrogen balance is difficult to determine. We propose here measures to reduce the loading of groundwater by nitrate. Using two coupled mathematical models, several irrigation and fertilizer management scenarios were simulated, on two years meteorological data, to investigate the effects of lumped and split fertilization schedules, for a representative set of crop and irrigation conditions. The model we propose here describes mathematically the biochemical reactions among different compounds of nitrogen in a soil-water-plant system. For a Romanian region, knowing the soil properties, meteorological data, crop type, evaporation, and the fertilizer concentration we, mathematically demonstrate that split fertilizer application reduce the amount of nitrates leaching toward the groundwater.
\end{abstract}

Keywords: soil, agriculture, groundwater pollution, water management, irrigation, fertilizer application, nitrogen, nitrates, mathematical model. 


\section{Introduction}

Soil and groundwater pollution with nitrates is a major environmental concern in Romania as well as in all countries with intensive and irrigated agriculture. Methods of fertilizer application, timing, relation of nitrogen to other nutrients, cropping systems and water management influence nitrates leaching. Because yields are very sensitive to nutrient deficiencies, farmers tend to exaggerate fertilizer use. Nitrogen is often excessively applied as insurance to obtain maximum yields, resulting in a chemical imbalance and consequent progressive degradation of soil.

The potential for $\mathrm{N}$ leaching depends on the type of fertilizer [8]. Organic fertilizers (natural or synthetic like urea) have a longer residence time in the soil and become slowly available for crops, and the potential for nitrate contamination from them is generally low. Some fertilizers which are derived from urea are less soluble in water. $\mathrm{NO}_{3}-\mathrm{N}$ fertilizers, which have the highest potential for leaching, are immediately available for crop uptake, and farmers prefer to apply them at peak demand periods. If nitrogen uptake by the roots is less than the amount of available $\mathrm{N}$, losses are likely to occur. The losses of ammonia fertilizers occur when the nitrification rate exceeds the $\mathrm{N}$ uptake rate by the crop.

Various management practices have been proposed to control $\mathrm{NO}_{3}$ leaching. For example crop rotation, controlled-release fertilizer, fine-tuned irrigation and $\mathrm{N}$ management based on soil testing programs, groundwater table control, reduced till or no-till practices. Many long-term studies have been developed to evaluate the effects of management practices on $\mathrm{NO}_{3}-\mathrm{N}$ leaching, aquifer water quality, and crop yields $[2,6,7]$.

Experimental research [6], demonstrated that split applications of fertilizers increase $\mathrm{N}$ root uptake and lower the amount of soluble $\mathrm{N}$ in the deeper soil profile. Nitrate leaching is considered to occur mainly during high precipitation or during irrigation. Several coupled models $[1,3]$, simulate water and $\mathrm{N}$ transport and $\mathrm{N}$ transformation.

In this paper we have studied the long-term effects of lumped and split application of fertilizers on $\mathrm{N}$ leaching through numerical simulations continuing some experimental and numerical approaches developed in the past $[4,5]$.

\section{Mathematical model for water and nitrogen transport in agricultural soils}

In this paper we consider a coupled mathematical model describing the water transfer through an agricultural soil and a simplified nitrogen cycle model to predict the nitrogen-nitrate concentration $\left(\mathrm{N}-\mathrm{NO}_{3}\right)$ at the boundary between unsaturated layer and groundwater (water-table).

The general plants-unsaturated soil-groundwater system described in the figure 1 contains the hydraulic connections between the atmospheric conditions, plants, soil layers, and groundwater. The plants develop theirs roots in the unsaturated layer (L1). The depth $\left(\mathrm{z}_{1}\right)$ of the roots layer depends on the crops 


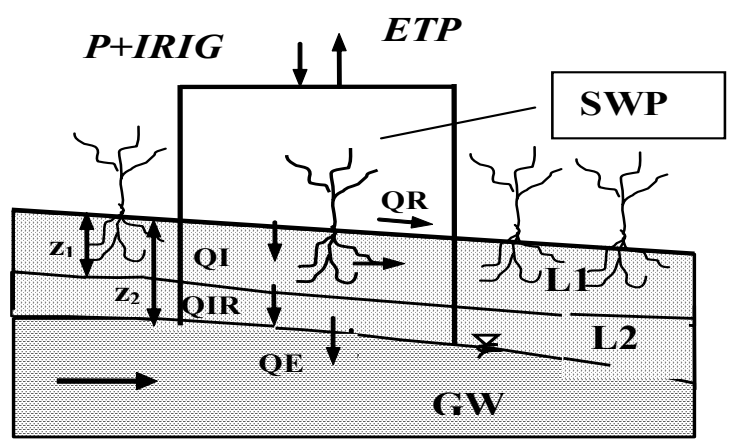

Figure 1: Definition of the soil-water-plant system (SWP).

type. Through the unsaturated layer without roots, (L2), lying between $\left(\mathrm{z}=\mathrm{z}_{1}\right)$ and the groundwater table $\left(\mathrm{z}=\mathrm{Z}_{2}\right)$, the water and the nitrates in excess can leach.

We will study the behavior of a soil-water-plant system (SWP) considering 1ha $\left(10^{4} \mathrm{~m}^{2}\right)$ surface of the general system (fig. 1). The water movement through the (SWP) system influences the nitrogen cycle and the plant's life.

\subsection{Mathematical model for nitrogen transport in agricultural soils}

The nitrogen concentration in agricultural soils depends on the inorganic and organic fertilizers, organic mater, meteorological and irrigation conditions, soil properties and crops type. The transformation study of the nitrogenous compounds is very complex. In the nitrogen cycle, the chemical, hydro chemical and physical interaction, convert and reconvert the organic nitrogen into mineral nitrogen with an influence on the life cycle. The adopted biochemical model [2] considers the nitrogen compounds transformations in SWP system (fig. 2).

We compute the concentration of each constituent $\mathrm{N}^{-\mathrm{NO}_{3}}{ }^{-}, \mathrm{N}_{-} \mathrm{NH}_{4}{ }^{+}$, N-Norg,

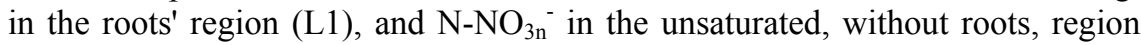
(L2). $\mathrm{NO}_{3 \mathrm{n}}$ is the nitrate concentration that reaches the water-table, and will be the pollutant concentration at the groundwater's upper boundary.

The nitrogen concentrations in each component (fig. 2) are related with the chemical entrances (fertilizers concentrations: AORG, AAMM, ANIT), and with the water dynamic in the soil.

The biochemical model [5] assumptions are:

1. sources of nitrogen in the soil results from the plant residues decay, microbial and animal material decay, and fertilization;

2. the nitrogen forms, considered in the model are nitrate $\left(\mathrm{NO}_{3}{ }^{-}\right)$, ammonium $\left(\mathrm{NH}_{4}{ }^{+}\right)$, and organic nitrogen Norg;

3. nitrogen transformations occur by means of mineralization (ammonification), immobilization (reorganization), nitrification and denitrification;

4. we will consider the nitrification one step reaction (neglecting the unstable nitrites form); 
5. the effects of precipitation reaction and biologic fixation are compensated by denitrification and volatilization;

6. a quasi-deterministic modelling approach was adopted to simulate plant nitrogen uptake $\left(\mathrm{NO}_{3}{ }^{-}\right)$. The nitrate uptake sub-model calculates the cumulative amount of nitrogen, taken by the crops since germination using a phenomenological equation proposed by Watts and Hanks [9].

The nitrification-denitrification processes, usually presented in literature as successive reactions of first order kinetics, are affected by: dissolved oxygen, micro-organisms, temperature, $\mathrm{pH}$ and carbon content.

The transfer functions between different nitrogenous forms (fig. 2) are related with the hydraulic parameters: rain or irrigation intensity $(\mathrm{P})$, the surface runoff (QR), and the moisture retention characteristic of the soil.

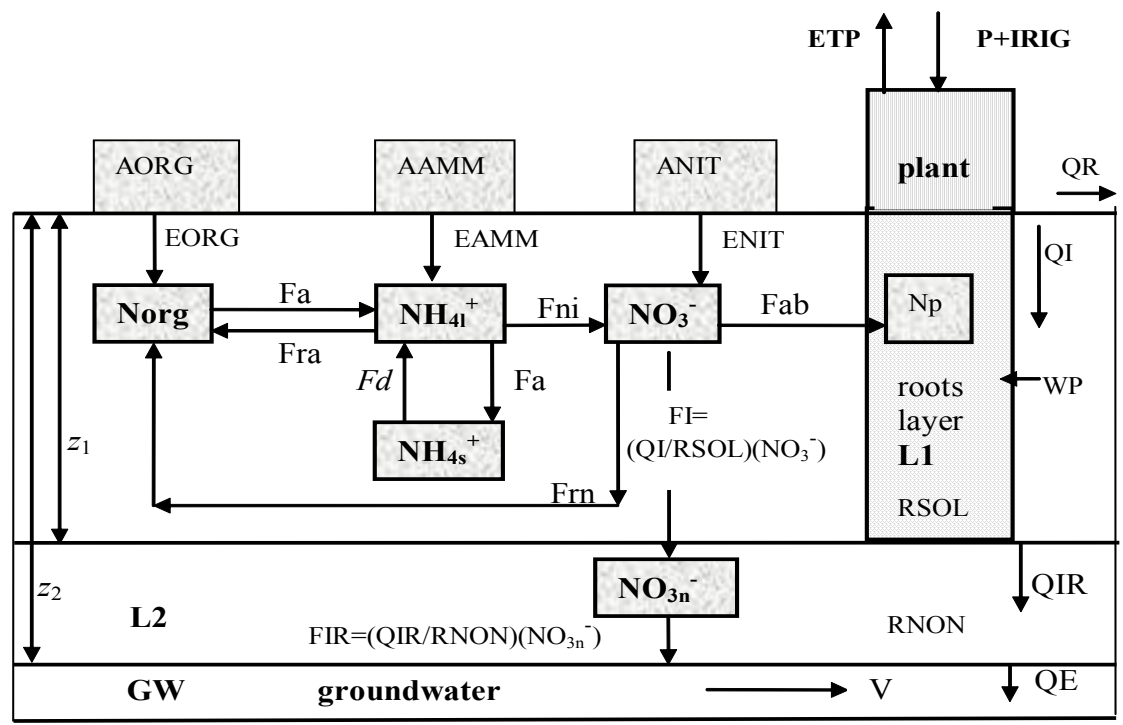

Figure 2: $\quad$ Simplified nitrogen cycle [3].

The nitrogen cycle (fig. 2) can be mathematically expressed like a six differential equations system:

$$
\begin{aligned}
& \frac{\mathrm{d}\left(\mathrm{NO}_{3}^{-}\right)}{\mathrm{dt}}=\mathrm{ENIT}-\mathrm{FI}+\mathrm{Fni}-\mathrm{Frn}-\mathrm{Fab}, \\
& \frac{\mathrm{d}\left(\mathrm{NH}_{41}^{+}\right)}{\mathrm{dt}}=\mathrm{EAMM}+\mathrm{Fam}-\mathrm{Fni}-\mathrm{Fra}+\mathrm{Fd}-\mathrm{Fa}, \\
& \frac{\mathrm{d}\left(\mathrm{NH}_{4 \mathrm{~s}}^{+}\right)}{\mathrm{dt}}=\mathrm{Fa}-\mathrm{Fd}, \\
& \frac{\mathrm{d}\left(\mathrm{NH}_{4}^{+}\right)}{\mathrm{dt}}=\mathrm{EAMM}+\text { Fam }- \text { Fni }- \text { Fra },
\end{aligned}
$$




$$
\begin{aligned}
& \frac{\mathrm{d}(\mathrm{Norg})}{\mathrm{dt}}=\mathrm{EORG}+\mathrm{Frn}+\mathrm{Fra}-\mathrm{Fam}, \\
& \frac{\mathrm{d}\left(\mathrm{NO}_{3 \mathrm{n}}^{-}\right)}{\mathrm{dt}}=\mathrm{FI}-\mathrm{FIR} .
\end{aligned}
$$

where: FI ( $\left.\mathrm{kg} \mathrm{ha}^{-1} / \mathrm{month}\right)$ is the nitrate flux through roots layer L1 (fig. 2), and depends on the ratio between the water flux QI $\left(\mathrm{m}^{3} \mathrm{ha}^{-1} /\right.$ month) carrying the nitrates, and the layer's L1 water content, RSOL $\left(\mathrm{m}^{3} \mathrm{ha}^{-1}\right)$, and on the nitrogennitrate concentration in this layer, $\left(\mathrm{NO}_{3}^{-}\right)\left(\mathrm{kg} \mathrm{ha}^{-1}\right)$. FIR $\left(\mathrm{kg} \mathrm{ha}^{-1} /\right.$ month) is the nitrate flux through unsaturated layer $\mathrm{L} 2$, and depends on the ratio between water flux QIR ( $\left.\mathrm{m}^{3} \mathrm{ha}^{-1} / \mathrm{month}\right)$, and the layer's L2 water content RNON $\left(\mathrm{m}^{3} \mathrm{ha}^{-1}\right)$, and on the nitrogen nitrate concentration in this layer, $\left(\mathrm{NO}_{3 \mathrm{n}}{ }^{-}\right)\left(\mathrm{kg} \mathrm{ha}^{-1}\right)$.

ANIT, AAMM, AORG are nitrogenous fertilizers $\left(\mathrm{kg} \mathrm{ha}^{-1}\right)$, on the soil surface.

ENIT, EAMM, EORG are nitrogenous fertilizers $\left(\mathrm{kg} \mathrm{ha}^{-1}\right)$, entering through the soil surface. These can be calculated taking into account the nitrogenous fertilizers solubility.

$$
\mathrm{ENIT}=(1-\mathrm{QR} / \mathrm{P}) \mathrm{ANIT}
$$

is the nitrate fertilizer quantity entering in SWP system considering ANIT solubility, the rain intensity, $\mathrm{P},\left(\mathrm{m}^{3} \mathrm{ha}^{-1} / \mathrm{month}\right)$, and the runoff discharge $\mathrm{QR}$ $\left(\mathrm{m}^{3} \mathrm{ha}^{-1} / \mathrm{month}\right)$. For $\mathrm{QR}=0$ (no runoff), all the nitrate fertilizer quantity enters the soil.

The ammoniacal and organic fertilizers are not soluble so all the quantities remain in the first layer (L1) and contribute to the nitrogen cycle:

$$
\mathrm{EAMM}=\mathrm{AAMM} \text { and } \mathrm{EORG}=\mathrm{AORG}
$$

Plant nitrogen uptake can be considered by transfer function Fab (a Michaelis-Menten approach):

$$
\mathrm{Fab}=\mathrm{B} \mathrm{f}_{\mathrm{pp}}{ }^{\prime}(\mathrm{t} / \mathrm{T})\left[\left(\mathrm{NO}_{3}{ }^{-}\right) /\left(\left(\mathrm{NO}_{3}{ }^{-}\right)+\mathrm{k}_{\mathrm{ab}}\right)\right] .
$$

where $\mathrm{B}$ is the potential (maximum) nitrogen-nitrate uptake by the plant during a life cycle, $\mathrm{t}$ is the time since germination started, $\mathrm{T}$ is the total crop's life, $\mathrm{k}_{\mathrm{ab}}$ is an equilibrium coefficient, and

$$
\mathrm{f}_{\mathrm{pp}}^{\prime}(\mathrm{t} / \mathrm{T})=\frac{\mathrm{dF}_{\mathrm{pp}}^{\prime}\left(\mathrm{t}^{\prime}\right)}{\mathrm{dt}} \frac{1}{\mathrm{~T}}, \mathrm{t}^{\prime}=\frac{\mathrm{t}}{\mathrm{T}} .
$$

$\mathrm{F}_{p p}{ }_{p \mathrm{p}}(\mathrm{t} / \mathrm{T}$ ) is the reduced function of potential cumulated uptake (fraction of total nitrogen uptake), and $\mathrm{t}^{\prime}=\mathrm{t} / \mathrm{T}$ is a fraction of growing season.

Considering the transfer functions in the chemical reactions, described in fig. 2, Fam, Fni, Fab, Fra, Frn, Fd, Fa, FI, FIR, the system (1) - (6) becomes:

$$
\begin{aligned}
& \frac{\mathrm{d}\left(\mathrm{NO}_{3}^{-}\right)}{\mathrm{dt}}=(1-\mathrm{QR} / \mathrm{P}) \text { ANIT }-\left(\mathrm{QI} / \mathrm{RSOL}^{-}\right)\left(\mathrm{NO}_{3}{ }^{-}\right)+\left[\mathrm{k}_{\mathrm{ni}} /\left(1+\mathrm{k}_{\mathrm{d}}\right)\right]\left(\mathrm{NH}_{4}{ }^{+}\right)- \\
& \mathrm{k}_{\mathrm{rn}}\left(\mathrm{NO}_{3}{ }^{-}\right)-\mathrm{B}\left[\left(\mathrm{NO}_{3}{ }^{-}\right) /\left(\left(\mathrm{NO}_{3}{ }^{-}\right)+\mathrm{k}_{\mathrm{ab}}\right)\right] \mathrm{f}_{\mathrm{pp}}{ }^{\prime}(t / \mathrm{T}) \text {, } \\
& \frac{\mathrm{d}\left(\mathrm{NH}_{4}^{+}\right)}{\mathrm{dt}}=\mathrm{AAMM}+\mathrm{k}_{\mathrm{am}}(\mathrm{Norg})-\left[\mathrm{k}_{\mathrm{ni}} /\left(1+\mathrm{k}_{\mathrm{d}}\right)\right]\left(\mathrm{NH}_{4}{ }^{+}\right)-\left[\mathrm{k}_{\mathrm{ra}} /\left(1+\mathrm{k}_{\mathrm{d}}\right)\right]\left(\mathrm{NH}_{4}^{+}\right), \\
& \frac{\mathrm{d}(\mathrm{Norg})}{\mathrm{dt}}=\mathrm{AORG}+\mathrm{k}_{\mathrm{rn}}\left(\mathrm{NO}_{3}{ }^{-}\right)+\left[\mathrm{k}_{\mathrm{ra}} /\left(1+\mathrm{k}_{\mathrm{d}}\right)\right]\left(\mathrm{NH}_{4}{ }^{+}\right)-\mathrm{k}_{\mathrm{am}}(\mathrm{Norg}),
\end{aligned}
$$




$$
\frac{\mathrm{d}\left(\mathrm{NO}_{3 \mathrm{n}}^{-}\right)}{\mathrm{dt}}=\left(\mathrm{QI} / \mathrm{RSOL}^{-}\left(\mathrm{NO}_{3}{ }^{-}\right)-(\mathrm{QIR} / \mathrm{RNON})\left(\mathrm{NO}_{3 \mathrm{n}}{ }^{-}\right),\right.
$$

where: $\mathrm{k}_{\mathrm{am}}, \mathrm{k}_{\mathrm{ra}}, \mathrm{k}_{\mathrm{ni}}, \mathrm{k}_{\mathrm{ad}}, \mathrm{k}_{\mathrm{rn}}$ are the rate values of chemical reactions, obtained by model calibration, QI $(\mathrm{mm} / \mathrm{month})$ is the entrance discharge through the unit surface, QIR ( $\mathrm{mm} / \mathrm{month})$ is the entrance discharge in the unsaturated region without roots, at $z_{1}$ depth, (fig. 1), RSOL $\left(\mathrm{m}^{3} / \mathrm{ha}\right)$ is the water content in the roots region (L1), and RNON ( $\left.\mathrm{m}^{3} / \mathrm{ha}\right)$ is the water content in (L2).

Starting from the numerical analysis referring to the asymptotical stability of the biochemical model [4] we looked at the system's (11)-(14) solution with biochemical input data and initial conditions, using numerical simulation.

Solution algorithm for biochemical model was implemented in Matlab (standard software) using the procedure ode15s (based on the numerical differentiation formulas (NDFs))/ode113 (variable order Adams-BashforthMoulton PECE solver).

\subsection{Mathematical model for water transport in agricultural soils}

We proposed a simple model to describe monthly, the water flow in a local SWP system [4]. Major assumptions of the water simulation model are:

1. the hydraulic balance has been done for two consequently years;

2. the monthly meteorological data are the same for two years;

3. for the wheat crops the effective rooting depth is $z_{1}=0.5 \mathrm{~m}$;

4. the water table is beneath the level $\mathrm{z}_{2}=1.5 \mathrm{~m}$ (fig. 1);

5. the initial soil water content corresponds to field capacity;

6. the total watering quantity during irrigation scheduling is calculated imposing to meet the optimum plants requirement;

7. the runoff doesn't occurs $(\mathrm{QR}=0)$.

For each month, $\mathrm{j}=1$ to $\mathrm{j}=12$, the water content in the $\mathrm{L} 1$ layer has to assure the field capacity: $\mathrm{RSOL} \geq \mathrm{Vc}$,

$$
\mathrm{Vc}=100\left(z_{1}\right) \mathrm{C}(\%) \rho_{\mathrm{b}},
$$

where $\mathrm{Vc}\left(\mathrm{m}^{3} / \mathrm{ha}\right)$ is the soil volumetric water content corresponding to field capacity $\mathrm{C}(\%), \rho_{\mathrm{b}}\left(\mathrm{kg} / \mathrm{m}^{3}\right)$ is the bulk density (dry soil mass/soil total volume).

The volumetric water content corresponding to field capacity is: $\theta(\%)=C(\%)$ $\rho_{\mathrm{b}}$ The volumetric water content $\theta(\%)$ could not be less than a residual value $\theta_{\mathrm{r}}$.

Another important coefficient is the wilting point of the soil, $\mathrm{Cw}(\%)$ in percents from the dry soil mass. The $\mathrm{Vw}\left(\mathrm{m}^{3} / \mathrm{ha}\right)$ is the soil volumetric water content corresponding to the wilting point of the soil, $\mathrm{Cw}(\%)$ :

$$
\mathrm{Vw}=100\left(\mathrm{z}_{1}\right) \mathrm{Cw}(\%) \rho_{\mathrm{b}}
$$

In our model we will use the assumption $\mathrm{RSOL} \geq \mathrm{Vc}$. If at the beginning of the month the L1 water content is less than $\mathrm{Vc},(\operatorname{RSOL}(\mathrm{j}-1)<\mathrm{Vc})$, the irrigation quantity IRIG(j) $\left(\mathrm{m}^{3} \mathrm{ha}^{-1} /\right.$ month) used in the month ' $\mathrm{j}$ ' will be:

$$
\operatorname{IRIG}(j)=\operatorname{Vc}-R S O L(j-1) \text {. }
$$

The total watering requirement (TWR) during irrigation scheduling is calculated so that it satisfies the water plant necessity, WP $\left(\mathrm{m}^{3} \mathrm{ha}^{-1} / \mathrm{month}\right)$, and the fertilization program. 


$$
\operatorname{TWR}\left(\mathrm{m}^{3} \mathrm{ha}^{-1} / \text { year }\right)=\sum_{\mathrm{j}=1}^{\mathrm{j}=12} \operatorname{IRIG}(\mathrm{j}) .
$$

Considering the runoff $\mathrm{QR}=0$, and

$$
\mathrm{QI}(\mathrm{j})=\operatorname{IRIG}(\mathrm{j})+\mathrm{P}(\mathrm{j})-\operatorname{ETP}(\mathrm{j}) \text {, }
$$

the water balance during each month gives the volumetric water content at the end of the month:

$$
\operatorname{RSOL}(j)=\operatorname{RSOL}(j-1)+[\operatorname{IRIG}(j)+P(j)-\operatorname{ETP}(j)-W P(j)-Q I R(j)] d t .
$$

In eqn. $(20), P(j)\left(\mathrm{m}^{3} \mathrm{ha}^{-1} / \mathrm{month}\right)$ is the monthly rain volume (on a 1 ha land surface). The evapotranspiration ETP(j) $\left(\mathrm{m}^{3} \mathrm{ha}^{-1} / \mathrm{month}\right)$ and $\mathrm{WP}(\mathrm{j})$ $\left(\mathrm{m}^{3} \mathrm{ha}^{-1} / \mathrm{month}\right)$ are input data for the hydraulic model. QIR(j) is the discharge percolating through L2 layer (fig. 1). If RSOL(j-1) is greater then saturated soil volumetric water content, $(\mathrm{RSOL}(\mathrm{j}-1)>\mathrm{RSAT})$, the water volume entering in L2 layer is:

$$
\operatorname{VIR}(j)=\operatorname{RSOL}(\mathrm{j}-1)-\mathrm{RSAT}=\mathrm{QIR}(\mathrm{j}) \mathrm{dt}
$$

Water balance for the layer $\mathrm{L} 2$ will be:

$$
R N O N(j)=R N O N(j-1)+[Q I R(j)-Q E(j)] d t,
$$

where $\mathrm{QE}(\mathrm{j})$ is the discharge percolating toward the groundwater.

If $\mathrm{RNON}(\mathrm{j}-1)$ is greater then saturated soil volumetric water content in $\mathrm{L} 2$, $(\mathrm{RNON}(\mathrm{j}-1)>\mathrm{RNONSAT})$ the water volume entering in the groundwater, $\mathrm{GW}$, layer is:

$$
\operatorname{VIN}(\mathrm{j})=\mathrm{RNON}(\mathrm{j}-1)-\mathrm{RNONSAT},=\mathrm{QE}(\mathrm{j}) \mathrm{dt}
$$

The hydraulic model gives the values IRIG, RSOL, RNON, QI, QIR, QE, VIR, VIN, (fig. 5), and QI(j)/RSOL(j), QIR(j)/RNON(j) used in the biochemical model (fig. 4).

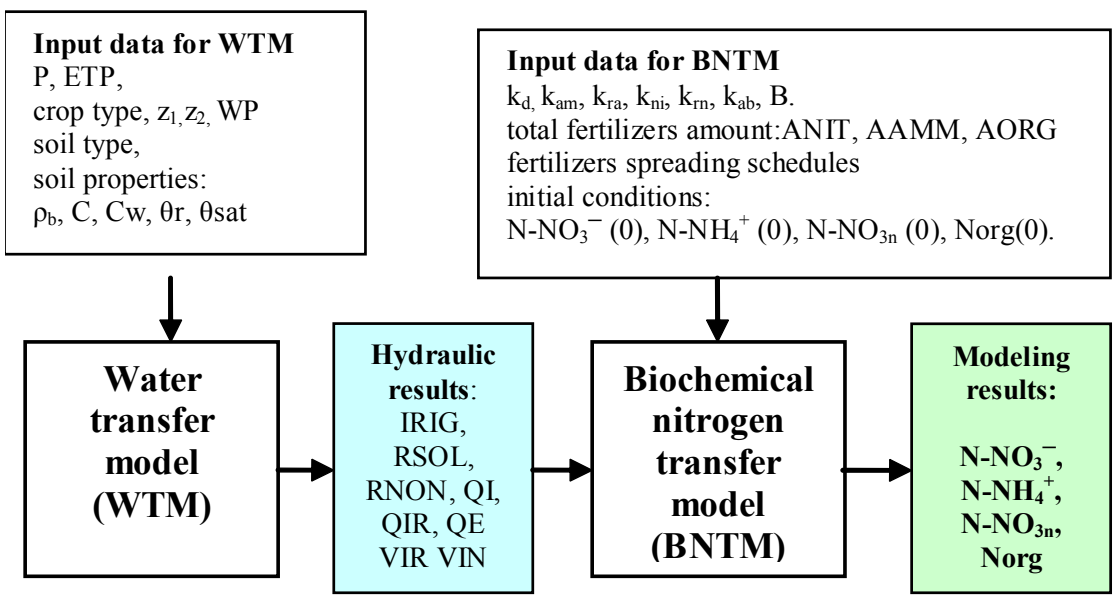

Figure 3: Coupled model flowchart. 


\section{Coupled hydraulic-biochemical model for a soil-water-plant system}

We propose a coupled model combining the mathematical model for water transport in agricultural soils described by eqns. (15)-(23), with the biochemical model represented by eqns. (11)-(14).

The goal of our research is to determine the concentration of $\mathrm{N}_{-} \mathrm{NO}_{3}{ }^{-}, \mathrm{N}-$ $\mathrm{NH}_{4}{ }^{+}, \mathrm{N}-\mathrm{NO}_{3 \mathrm{n}}$, and Norg, and to demonstrate that split fertilizer application reduce the amount of nitrates leaching toward the groundwater.

The hydraulic model computes IRIG, RSOL, RNON, QI, QIR, QE, VIR, VIN, (fig. 4), used in the biochemical model.

QI/RSOL and QIR/RNON (fig. 5) are the hydrological parameters taken as monthly average values from the water transfer model.

Solving the system of equations (11)-(14), the concentration of ${\mathrm{N}-\mathrm{NO}_{3}}^{-}, \mathrm{N}-$ $\mathrm{NH}_{4}^{+}, \mathrm{N}-\mathrm{NO}_{3 \mathrm{n}}$, Norg are calculated for two years.

We have studied three scenarios (different fertilizers schedule) for wheat crops with 9 months vegetation period and the plant nitrate consumption computed using the Michaelis-Menten approximation (9) and (10).

\subsection{Input data and modelling objectives}

We consider a wheat crop (15 X-15VII) developing the roots in an unsaturated soil with two layers L1, L2 (fig. 1) with $\mathrm{z}_{1}=0.5 \mathrm{~m}$, and $\mathrm{z}_{2}=1.5 \mathrm{~m}$. The soil is a loamy send, and its properties are: $\rho_{\mathrm{b}}=1.27\left(\mathrm{~kg} / \mathrm{m}^{3}\right) ; \mathrm{C}=17.3(\%) ; \mathrm{Cw}=7.5(\%)$; $\theta \mathrm{r}(\%)=0.09(\%) ; \theta \operatorname{sat}(\%)=41(\%)$.

The meteorological and water crops demand input data, P, ETP and WP (Table 1) are total monthly value, in (mm), and they are plotted in fig. 4 .

Table 1: Meteorological and water crops demand data ( $\mathrm{mm} / \mathrm{month})$.

\begin{tabular}{|c|c|c|c|c|c|c|c|c|c|c|c|c|}
\hline j & 1 & 2 & 3 & 4 & 5 & 6 & 7 & 8 & 9 & 10 & 11 & 12 \\
\hline month & $\mathrm{X}$ & $\mathrm{XI}$ & $\mathrm{XII}$ & $\mathrm{I}$ & $\mathrm{II}$ & $\mathrm{III}$ & $\mathrm{IV}$ & $\mathrm{V}$ & $\mathrm{VI}$ & $\mathrm{VII}$ & VIII & IX \\
\hline P & 70 & 50 & 40.1 & 38.4 & 42.1 & 86.4 & 76.7 & 58.8 & 75.1 & 72.4 & 72.1 & 78.4 \\
\hline ETP & 25.0 & 22.0 & 10.0 & 10.3 & 10.3 & 14.0 & 20.4 & 54.0 & 65.8 & 78.0 & 78.0 & 58.0 \\
\hline WP & - & - & - & - & - & 45 & 81 & 123 & 99 & - & - & - \\
\hline
\end{tabular}

The biochemical model parameters are: $\mathrm{k}_{\mathrm{d}}=0.35, \mathrm{k}_{\mathrm{am}}=0.06 \mathrm{month}^{-1}, \mathrm{k}_{\mathrm{ra}}=1.1$ month $^{-1}, \mathrm{k}_{\mathrm{ni}}=2.2$ month $^{-1}, \mathrm{k}_{\mathrm{rn}}=0.8$ month $^{-1}, \mathrm{k}_{\mathrm{ab}}=3 \mathrm{~kg} \mathrm{ha}^{-1}, \mathrm{~B}=218 \mathrm{~kg} \mathrm{ha}^{-1} /$ year.

The total fertilizers amount is $240 \mathrm{~kg} \mathrm{ha}^{-1} /$ year. (ANIT $=140 \mathrm{~kg} \mathrm{ha}^{-1} /$ year, $\mathrm{AAMM}=60 \mathrm{~kg} \mathrm{ha}^{-1} /$ year, $\mathrm{AORG}=40 \mathrm{~kg} \mathrm{ha}^{-1} /$ year).

Table 2 contains the fertilizers spreading schedules, (F.S.), for each studied scenario. For all of the three scenarios, the initial conditions are:

$$
\mathrm{N}-\mathrm{NO}_{3}{ }^{-}(0)=\mathrm{N}^{-N_{4}}{ }_{4}^{+}(0)=\mathrm{N}-\mathrm{NO}_{3 \mathrm{n}}(0)=\operatorname{Norg}(0)=10 \mathrm{~kg} \mathrm{ha}^{-1} \text {. }
$$

\subsection{Modelling results}

The figures 4 and 5 show the water transfer model results for one year (IRIG, RSOL, RNON). IRIG(j) $\left(\mathrm{m}^{3} \mathrm{ha}^{-1} / \mathrm{month}\right)$ is the total irrigation water volume used during the $j$-th month. 


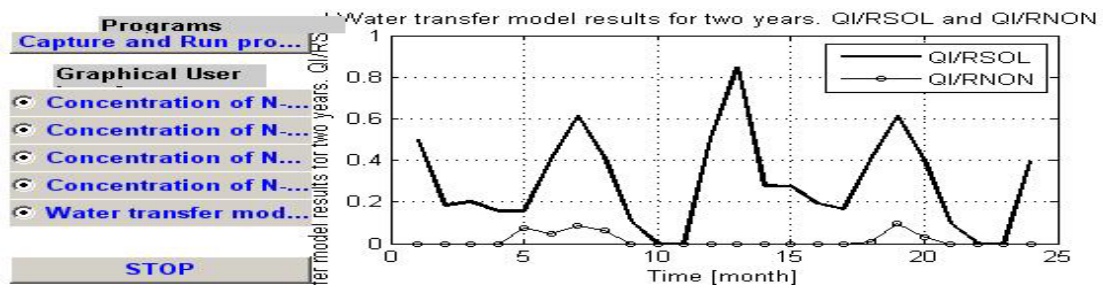

Figure 4: Water transfer model results for two years. Monthly values for QI/RSOL and QIR/RNON.

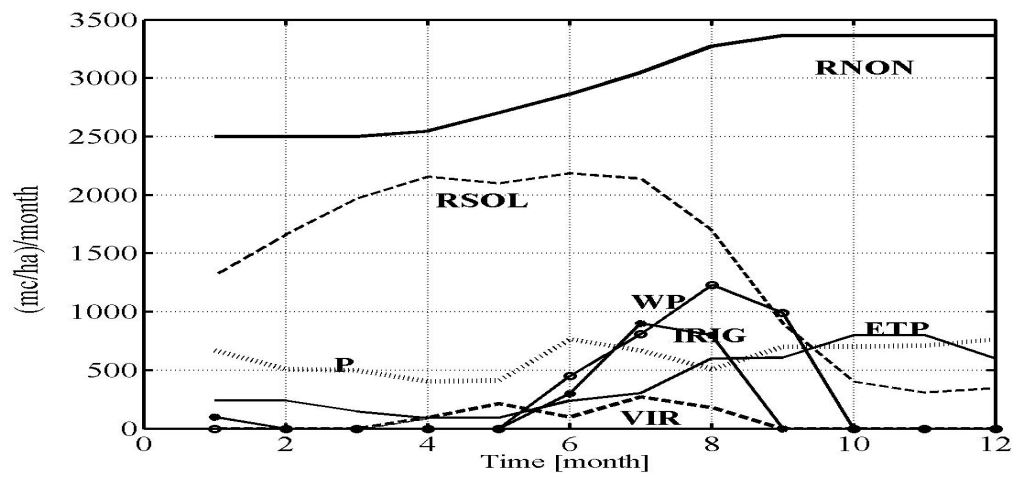

Figure 5: Water transfer model results for one year. All computed values are in $\left(\mathrm{m}^{3} / \mathrm{ha}\right) /$ year.

The results for two years modeling of a local SWP system are presented in the figures $6,7,8$ and 9 .

Three schedules (F.S.) for fertilizers spreading $\left(\mathrm{kg} \mathrm{ha}^{-1}\right)$ are considered (Table 2).

Table 2: $\quad$ Fertilization schedule.

\begin{tabular}{|c|c|c|c|c|c|c|c|c|c|c|c|c|}
\hline$j$ & 1 & 2 & 3 & 4 & 5 & 6 & 7 & 8 & 9 & 10 & 11 & 12 \\
\hline month & $\mathrm{X}$ & $\mathrm{XI}$ & $\mathrm{XII}$ & $\mathrm{I}$ & $\mathrm{II}$ & $\mathrm{III}$ & $\mathrm{IV}$ & $\mathrm{V}$ & $\mathrm{VI}$ & VII & VIII & IX \\
\hline F.S. 1 & 48 & - & - & - & - & 48 & 96 & 48 & - & - & - & - \\
\hline F.S. 2 & 240 & - & - & - & - & - & - & - & - & - & - & - \\
\hline F.S. 3 & 60 & - & - & - & - & 60 & 60 & 60 & - & - & - & - \\
\hline
\end{tabular}

First scenario FS1, is a four-split fertilization with different spreading quantities. The second FS2 is a lumped fertilization using all the quantity once, and FS3 is a four-split fertilization with equal spreading quantities.

The value of total nitrogenous fertilizer $\left(240 \mathrm{~kg} \mathrm{ha}^{-1} /\right.$ year $)$ contains. ANIT $=140 \mathrm{~kg} \mathrm{ha}^{-1} /$ year, AAMM=60 kg ha $/$ year, AORG=40 kg ha $1 /$ year, and the split quantities preserved that proportion. 


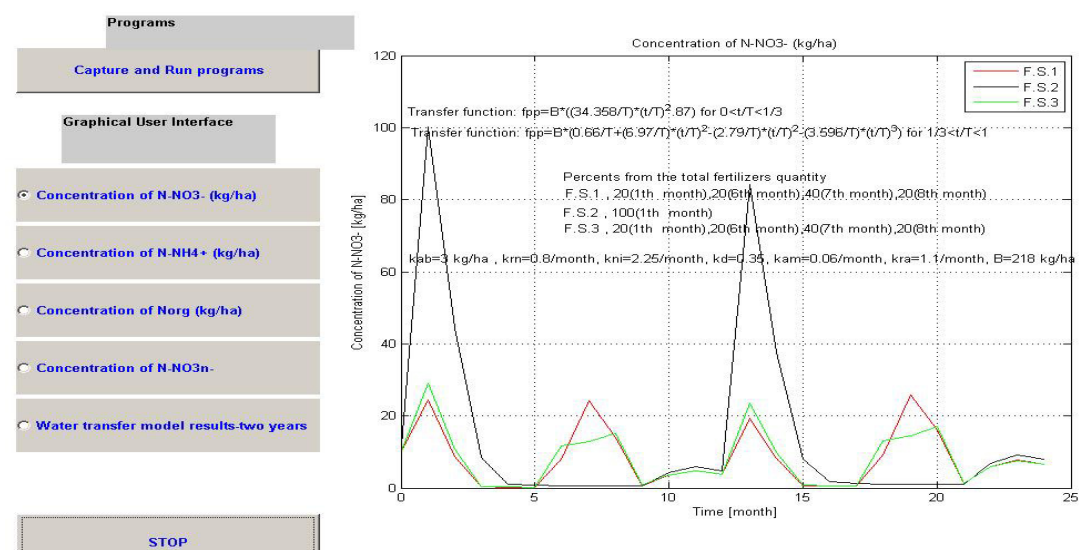

Figure 6: Concentration of $\mathrm{N}_{-} \mathrm{NO}_{3}^{-}(\mathrm{kg} / \mathrm{ha})$ for three fertilization scenarios.
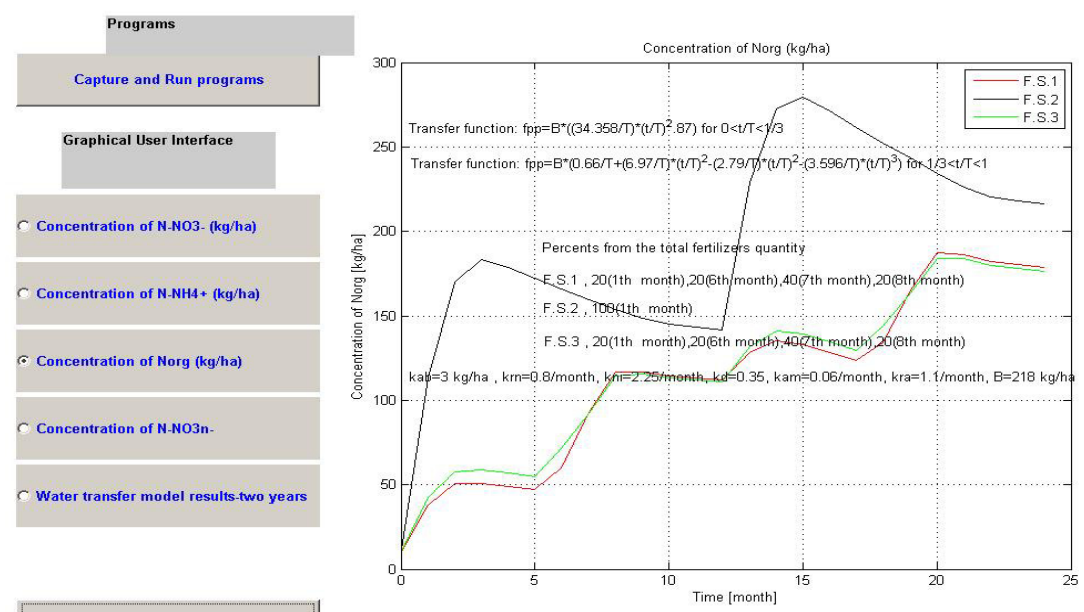

Figure 7: Concentration of Norg $(\mathrm{kg} / \mathrm{ha})$ for three fertilization scenarios.

The numerical results show that in all scenarios the $\left(\mathrm{N}-\mathrm{NO}_{3}{ }^{-}\right)$values decrease rapidly during the first four months of the year because the soil is almost saturated and the water is drained through the roots layer L1 to the L2 (where the $\left(\mathrm{N}-\mathrm{NO}_{3 n}{ }^{-}\right)$values increase). Also, the plants roots are growing during these months (Norg increases).

In FS1 and FS3 scenarios the plants do not have enough nitrates (in the months 3-5). The bests schedule for fertilizers spreading is the third because it achieves the minimal concentration of $\mathrm{N}-\mathrm{NO}_{3 n}{ }^{-}$(fig.8) and more $\mathrm{N}-\mathrm{NO}_{3}{ }^{-}$in L1 layer (fig. 6). The lumped method (FS1) implies the greater nitrates values in the layer L2, and so that layer can be a pollution source for groundwater. 

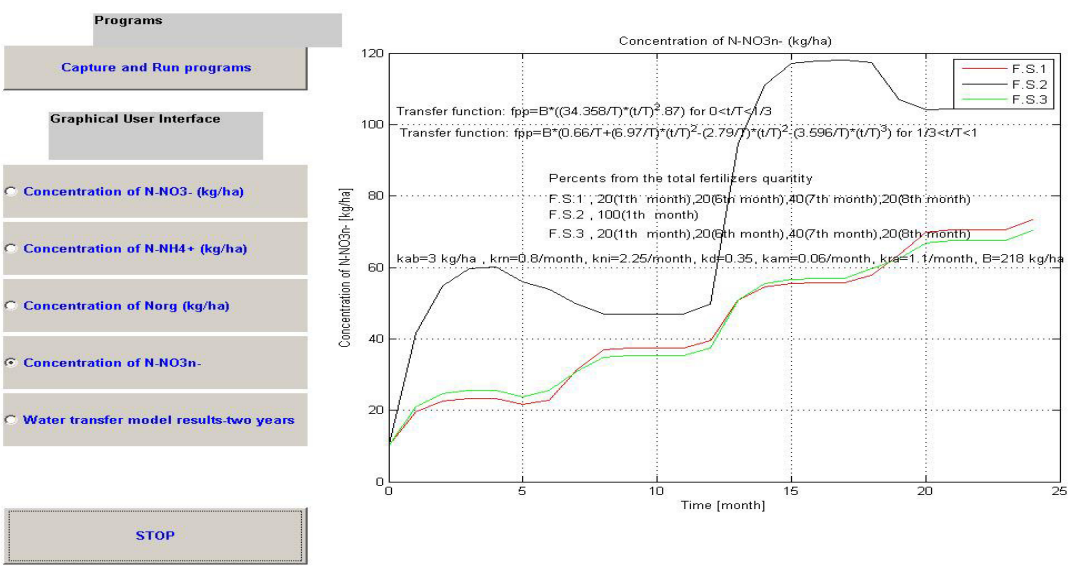

Figure 8: $\quad$ Concentration of $\mathrm{N}_{-} \mathrm{NO}_{3 \mathrm{n}}{ }^{-}(\mathrm{kg} / \mathrm{ha})$ for three fertilization scenarios.
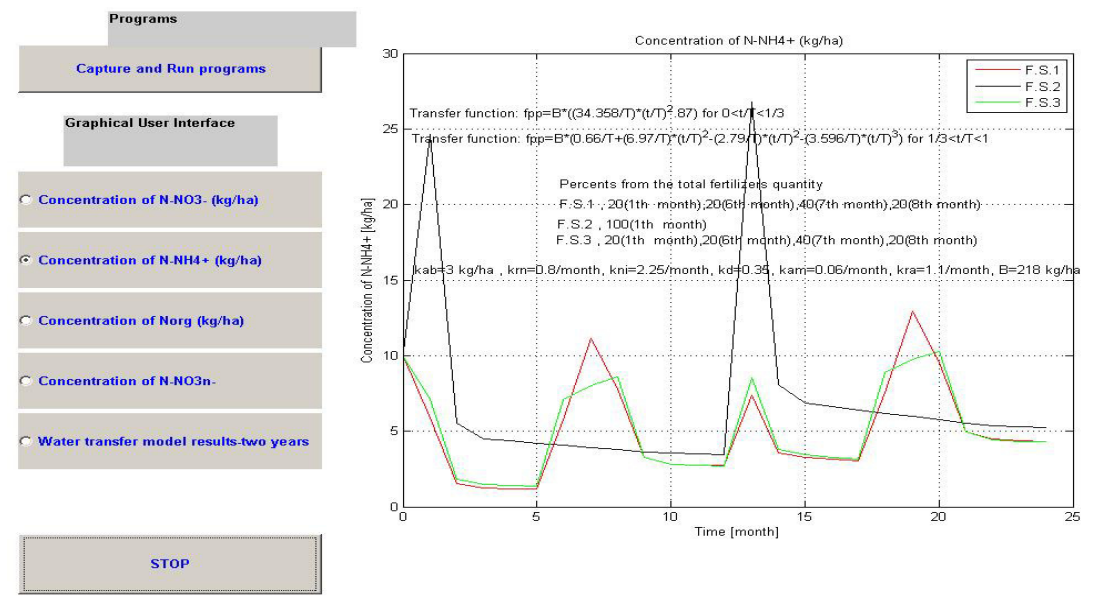

Figure 9: $\quad$ Concentration of $\mathrm{N}-\mathrm{NH}_{4}{ }^{+}(\mathrm{kg} / \mathrm{ha})$ for three fertilization scenarios.

\section{Conclusions}

In this paper we consider a simple model connecting the water transfer with the nitrogen cycle model to predict the nitrogen-nitrate concentration at the boundary between unsaturated layer and the groundwater.

Our numerical model can compute the concentration of $\mathrm{NO}_{3}{ }^{-}, \mathrm{NH}_{4}{ }^{+}$, Norg in the unsaturated soil layer L1, that has roots belonging to the crop plants and the concentration of $\mathrm{NO}_{3 \mathrm{n}}{ }^{-}$in the layer that has no roots, $\mathrm{L} 2$.

The mathematical model proposed to describe the nitrogen transfer into unsaturated soils is a simple, accurate model, and can be used for daily forecasts, as well as for monthly or annual forecasts. 
The $\mathrm{N}$ leaching depends on precipitation and irrigation events, on soil type, and on plant $\mathrm{N}$ uptake behavior.

The water and nitrogen transport simulation demonstrated that fertilizer management can significantly control the transfer of nitrates through the soil layers toward the groundwater.

Split applications increase nitrates root uptake and lower the amount of soluble nitrogen compounds in the deeper soil profile.

The rapports between the maximum concentrations in lumped and in split applications are: $(100 / 30)$, for $\mathrm{N}^{-\mathrm{NO}_{3}}{ }^{-},(60 / 25)$, for $\mathrm{N}-\mathrm{NO}_{3 \mathrm{n}}{ }^{-}$and $(25 / 7)$ for $\mathrm{N}-$ $\mathrm{NH}_{4}^{+}$.

In comparison with lumped applications, split fertilizer applications were found to consistently reduce the amount of $\mathrm{N}$ leaching.

\section{Acknowledgements}

This research was developed in the frame of a Romanian National Research Program IDEI, grant 189/2007, sponsored by CNCSIS, Romania.

\section{References}

[1] Antonopoulos, V.Z., \& Wyseure, G.C.L., Modeling of water and nitrogen dynamics on an undisturbed soil and a restored soilafter open-cast mining, Agric. Water Manage., 37, pp. 21-40, 1998.

[2] Delgado, J.A., Riggenbach, R.R., Sparks, R.T., Dillon, M.A., Kawanabe, L.M., \& Ristan, R.J., Evaluation of nitrate-nitrogen transport in a potatobarley rotation, Soil Sci. Soc. Am. J., 65, pp. :878-883, 2001.

[3] Geng, Q.Z., Modélisation conjointe du cycle de l'eau et du transfert des nitrates dans un système hydrologique, Thèses E N S M de Paris, 1988.

[4] Marinov, A.M. \& Petrovici, T., On nitrogen compounds transport in unsaturated soil: analytical and numerical solutions, UPB Sci. Bul., Series D, 70(4), pp. 251-262, 2008.

[5] Marinov, A.M. Diminescu, M.A., Experimental research and mathematical modelling of soil and groundwater contamination with nitrogen compounds, Proc. of the IX-th. Int. Conf. on Water pollution, eds. C.A. Brebia, WIT Transactions, UK, pp.115-126, 2008.

[6] Nakamura, K., Haster, T., Hirono, Y., Horino, H. \& Mitsuno, T., Assessment of root zone nitrogen leaching as affected by irrigation and nutrient management practices, Vadose Zone Journal, 3, pp.1353-1366, 2004.

[7] Power, J.F., Wiese \& R, Fowerday, D., Managing farming systems for nitrate control: A research review from management systems evaluation areas, J. Environ. Qual. 30, pp.1866-1880, 2001.

[8] Pereira, L.S.\& Quelhas dos Santos, J., Fertilizer and water application, and control of nitrate pollution. Management issues, NATO Advanced Research Workshop on Nitrate Contamination: Exposure, Consequences, and Control, Lincoln, Nebraska, USA, pp.141-162, 1990.

[9] Watts, D.G.\& Hanks, R.J., A soil-water-nitrogen model for irrigated corn on sandy soil, Soil Sci. Soc. Amer. J., no. 42, pp.492-499, 1978. 